JEL: C12, G51

DOI: 10.5937/industrija48-26003

UDC: $336.744: 519.23$

004.738.5:339

Original Scientific Paper

\title{
Measuring the effects of Bitcoin forks on selected cryptocurrencies using event study methodology
}

\author{
Article history: \\ Received: 5 April 2020 \\ Sent for revision: 13 August 2020 \\ Received in revised form: 8 September 2020 \\ Accepted: 27 September 2020 \\ Available online: 19 October 2020
}

\begin{abstract}
The objective of the study is to determine whether the Bitcoin forks have produced significant effects on the cryptocurrency market. The event study methodology is used in this paper in order to determine the statistical significance of the abnormal return of leading cryptocurrencies after three Bitcoin forks. The forks were viewed as three isolated events, with the estimations windows and the event windows constructed separately for each of them. There were statistically significant negative effects related to the creation of Bitcoin Gold and Bitcoin SV. Contrary to expectations, there was no statistically important effect throught out the most famous Bitcoin forking and emergence of Bitcoin Cash. Although cryptocurrencies are a current topic, the literature lacks quantitative research dealing with price changes. Without quantitative analysis, it is difficult to conclude whether the return change is a consequence of a statistically significant event The analysis would therefore provide the tool to determine the statistical significance of their impact on the market. A small number of observed cryptocurrencies is the main limitation of
\end{abstract}

\footnotetext{
${ }^{1}$ University of Kragujevac, Faculty of Economics, ntomic@kg.ac.rs
} 
this research. Future researches could cover a wider scope of the market and include other famous cases of forking, for example, the Ethereum forks.

Keywords: Bitcoin, forks, event study, cryptocurrencies.

\section{Merenje efekata račvanja Bitcoina na odabrane kriptovalute primenom metodologije studije događaja}

Apstrakt: Istraživanje ima za cilj da utvrdi da li su granjanja Bitkoina stvorila statistički značajan efekat na tržištu kriptovaluta. U radu je korišćenja metodologija studije događaja za utvrđivanje postojanja ekstra prinosa kod vodećih kriptovaluta nakon tri granjanja Bitkoina. Granjanja su posmatrana kao tri nezavisna događaja, za koji su posebno konstruisani periodi procene $i$ periodi događaja. Utvrđeno je postojanje statistički značajnog negativnog ekstra prinosa nakon stvaranja Bitcoin Gold i Bitcoin SV kriptovaluta. Suprotno očekivanjima, nije bilo statistički značajnog efekta prilikom najpoznatijeg slučaja granjanja i nastanka kriptovalute Bitcoin Cash.lako su kriptovalute aktuelna tema, nedostaju kvantitativna istraživanja promena cena. Bez kvantitativne analize, teško je doneti zaključak da li je promena prinosa rezultat događaja koji stvara statistički značajan događaj. Stoga bi analiza pružila oruđe za utvrđivanje njihovog uticaja na tržište. Ključno ograničenje ovog istraživanja je manji broj posmatranih kriptovaluta. Naredna istraživanja bi mogla pokriti širi opseg tržišta i uključiti $i$ druge slučaje granjanja, poput onih vezanih za kriptovalutu Ethereum.

Ključne reči: Bitcoin, račvanje, studija događaja, kriptovalute.

\section{Introduction}

Cryptocurrencies have been in the focus of both the academic and the general public for the last several years. They introduced a blockchain, cryptographical technology that enables decentralized management of large databases (Nakamoto, 2008). Since then, potential high rates of return have attracted a large number of speculative investors. By August 2020, over 6500 different cryptocurrencies have been registered, with a total market value of almost US\$ 370 billion (coinmarketcap.com). However, cryptocurrencies still are not significant in modern payment systems. Frequent and sudden changes in value made them suitable for speculative investments only (Enoksen et al., 2020).

Investing in cryptocurrencies brought extremely high rates of return over time. However, periods of value growth were usually followed by periods of pronounced decline (Borgards, \& Czudaj, 2020.). Therefore, in the professional 
literature and the general public, investing in cryptocurrencies is referred to as extremely risky business, with no guarantee of return, and also without any protection for investors. In the general public, investing in cryptocurrencies is often equated with investing in Bitcoin. Although Bitcoin is the first and the most widely used cryptocurrency, other cryptocurrencies have proven to be better investment opportunities in certain situations. Thus, 2017 remained remembered as the calendar year during which the highest number of cryptocurrencies recorded their highest growth rates. As can be seen in Table 1 , Bitcoin was not in the top 10 cryptocurrencies on that list, as it recorded lower growth rates than the leaders.

Table 1: Cryptocurrencies listed by annual value growth in the period January 1-December 31, 2017

\begin{tabular}{rl|c}
\hline Cryptocurrency & Value growth in percentages \\
\hline 1. & Ripple & $36018 \%$ \\
\hline 2. & NEM & $29842 \%$ \\
\hline 3. & Ardor & $16809 \%$ \\
\hline 4. & Stellar & $14441 \%$ \\
\hline 5. & Dash & $9265 \%$ \\
\hline 6. & Ethereum & $9162 \%$ \\
\hline 7. & Golem & $8434 \%$ \\
\hline 8. & Binance Coin & $8061 \%$ \\
\hline 9. & Litecoin & $5046 \%$ \\
\hline 10. & Omise GO & $3315 \%$ \\
\hline 14. & Bitcoin & $1318 \%$ \\
\hline
\end{tabular}

Source: https://cointelegraph.com/news/the-cream-of-the-crypto-crop-10-best-performing-assets$\underline{i n-2017}$

However, the overall size of the cryptocurrency market makes Bitcoin absolutely dominant. At the beginning of 2020 , Bitcoin accounted for over $2 / 3$ of otal capitalization and about $1 / 3$ of total daily trade volume. The previously mentioned could be seen in Table 2. Therefore, it is not surprising that oscilation of Bitcoin shape the overall market.

Table 2: Market capitalization and daily trade volume in USD on March 20, 2020.

\begin{tabular}{cl|c|c}
\hline \multicolumn{2}{c|}{ Cryptocurrency } & Market capitalization & Daily trade volume \\
\hline 1. & Bitcoin & 94856122594 & 37332505332 \\
\hline 2. & Ether & 12508122599 & 11347849498 \\
\hline 3. & Ripple & 6241530713 & 1981257358 \\
\hline
\end{tabular}




\begin{tabular}{rl|c|c}
\hline 4. & Tether & 4617518028 & 45475640653 \\
\hline 5. & Bitcoin Cash & 3254692843 & 2946981246 \\
\hline 6. & Litecoin & 2135651344 & 3198929501 \\
\hline 7. & Bitcoin SV & 2100658519 & 1552613809 \\
\hline 8. & EOS & 1787100955 & 2400788211 \\
\hline 9. & Binance coin & 1558847465 & 265139102 \\
\hline 10. & LEO & 956983518 & 9737767 \\
\hline
\end{tabular}

Source: https://coinmarketcap.com

The hard fork is the process during which a unique blockchain splits into two independent ones. Essentially, a new blockchain separates from the old one and continues to function parallel with it, but as a completely independent system (De Filippi, \& Loveluck, 2016). The fork could result from the tendency of malicious participants to persuade the rest of the network that fake transactions (for example, double-spending the same funds) are true ones (Lee, \& Chen, 2017). Such forks are of short duration if malicious participants do not have support of at least $51 \%$ of all network participants. However, a hard fork occurs due to rule changes, after which practically two parallel blockchains are created: one funtioning according to the old rules and the other operating under the new rules. As the rules are not the same, they continue to function without interference (Islam, Mäntymäki \& Turunen, 2019).

Although cryptocurrencies are a contemporary topic, there is no sufficient quantitative research dealing with price changes. The sign of the return changes several times during the day. Without quantitative analysis, it is difficult to conclude when the change in return is the result of daily oscillations, and when it is the consequence of an event that produces a statistically significant effect. Cryptocurrency forks are common occurrences and are not only related to Bitcoin, so the analysis should determine the statistical significance of their impact on the market.

The subject of the paper is the effect of Bitcoin forks on the return of selected cryptocurrencies. The objective of the study is to determine whether the forks produced significant effects on the cryptocurrency market. The event study methodology will be used to quantify the statistical significance of the effects. The second section of the paper will define the events that will be analyzed and provide the literature review. The third section will introduce the methodology that will be used in the research. The results and discussion will be provided in the fourth section of the paper. 


\section{Literature review}

The event study methodology was used to examine the impact of unexpected events on the cryptocurrency market. Ante (2019) examined the impact of listing on exchanges on a wide sample of 180 cryptocurrencies. He concluded that there was an average positive abnormal return, which was higher for those cryptocurrencies that were listed on a smaller number of exchanges. Shanaev et al. (2019) analyzed the impact of $51 \%$ attacks on returns, on a sample of 13 cryptocurrencies. They concluded that the negative impact was so stable that it stayed statistically significant even when the event window was changed. Hashemi et al. (2020) analyzed the impact of announcements, concluding that the cumulative abnormal return was higher in negative announcements than in positive ones. Among the analyzed announcements, there was the Bitcoin fork which created Bitcoin Cash. The authors concluded that it had a slightly positive effect.

Thompson (2017) explained that due to the expectations, the price would have to rise before the forking and would have to fall immediately after it. However, he states that the largest part of the fall was absorbed by the newly created cryptocurrency, and not by the existing one. Agosto \& Cafferata (2020) analyzed price bubbles in the cryptocurrency market, and concluded that Bitcoin had shown growth patterns in the period from August to September in 2017, and the period from the end of October to the beginning of December in 2017 - immediately after two forks. Bouri, Roubaud \& Shahzad (2020) stated that two Bitcoin forks in the second half of 2017 were among the key factors that contributed to the decline of the cryptocurrency market during 2018. Kumar \& Adandaro (2019) analyzed the interdependence of returns of different cryptocurrencies using the GARCH method. They concluded that Bitcoin forks during 2017 had negligible effects on overall returns, but that they significantly contributed to increasing of correlation between other cryptocurrencies' returns (such as Ethereum, Ripple and Litecoin).

Three separated events are to be observed for the research purposes. The first event took place on August 1, 2017. A group of activists and developers involved in the Bitcoin network requested a protocol change that would allow an increase in the size of the block (Williams-Grut, \& Price, 2017). As the majority of participants rejected the proposal, the initial group started a fork, which resulted in the emergence of a new cryptocurrency known as Bitcoin Cash $(\mathrm{BCH})$. Participants who updated the mining software to the latest version accessed the new currency, and received the same amount of Bitcoin Cash coins for an amount of Bitcoin they previously owned. 
The second event concerns the next Bitcoin fork, which happened on October 24 of the same year (Chaparro, 2017). A new group of activists proposed creation of a different mining algorithm, called Equicash. According to the standard algorithm, owners of specialized Bitcoin mining devices - rigs - had an advantage over miners who were using computer systems. As the proposal was not accepted in the wider community, the initial group started a fork, which resulted in the emergence of a new cryptocurrency known as Bitcoin Gold (BTG). Participants who updated to this new mining protocol accessed the new currency, and received the same amount of Bitcoin Gold coins for an amount of Bitcoin they had previously owned.

The third event is the fork of the Bitcoin Cash, which emerged during the first fork of Bitcoin (Fenech, 2018). It happened on November 15, 2018, when one of the factions created a separate cryptocurrency called Bitcoin Satoshi Vision or abbreviated Bitcoin SV (BSV). Unlike the previous two situations, the exchange of values was not performed in 1:1 ratio, as Bitcoin SV coins recorded a significant decline in value.

In this research, three hypotheses will be formulated, with one hypothesis per each of these events. Bearing in mind the aforementioned claims, all hypotheses would assume a negative impact of the forks on the cryptocurrency market.

$H_{1}$ : The fork that created Bitcoin Cash has produced negative effects on the cryptocurrency market.

$\mathrm{H}_{2}$ : The fork that created Bitcoin Gold has produced negative effects on the cryptocurrency market.

$H_{3}$ : The fork that created Bitcoin SV has produced negative effects on the cryptocurrency market.

\section{Methodology and data}

The essence of the event study is to determine the normal return of observed assets on the basis of a trend, and to compare it with historical returns. A positive difference between historical and normal return represents a positive abnormal return, while a negative difference represents a negative abnormal return. Their values during event window are important for statistical analysis. In order to determine the normal return, it is necessary to observe both the historical returns of all asset units that would be subjected to analysis and the market indicator over a long period of time. This time interval is called the estimation window. Normal return for each unit of observed asset would be 
determined on the basis of its historical returns and historical returns of market indicator. Asset units in this paper are selected cryptocurrencies.

Although the initial papers in this field were published as early as the 1930s (Dolley, 1933), the contemporary methodology of event study was applied for the first time in research by the Nobel Prize winner Fama (Fama et al., 1969). Key contributions to methodology refining were provided by Brown, \& Warner (1980; 1985), Dodd, \& Warner (1983) and Corrado (1989). The methodology is based on regression, parametric tests and non-parametric statistical tests.

There are several methods for calculating normal return. In this paper, authors will use the most common one - market model. If $R_{m t}$ denotes the return of a market indicator at time $t$, then the return of cryptocurrency $i$ in the same moment can be denoted by $R_{i t}$.

$E\left(R_{i t}\right)=\alpha_{i}+\beta_{i} R_{m t}+\varepsilon_{i t}$

The equation (1) is used for determining the expected value of $R_{i t} \varepsilon_{i t}$ is statistically speaking a random error, that is, the effect of residual factors (as there is possibility that individual factors have a strong influence on return on daily level), which has the expected value $E\left(\varepsilon_{i t}\right)=0$ and the variance $\operatorname{var}\left(\varepsilon_{i t}\right)=\sigma_{i}^{2}$, which means it has a normal distribution. $\alpha_{i}$ and $\beta_{i}$ denote parameters of the market model and also they are obtained by the regression process of the historical returns of each cryptocurrency against the historical returns of the market indicator.

By subtracting the calculated expected return $E\left(R_{i}\right)$ from historical values of return, it is possible to determine the abnormal return:

$A R_{i t}=R_{i t}-E\left(R_{i t}\right)$

$\operatorname{Var}\left(A R_{i t}\right)=\sigma_{\varepsilon_{i}}^{2}$

$A R_{i t}$ denotes the abnormal return of the cryptocurrency $i$ on day $t$, which belongs to the event window. In practice, abnormal return will always exist, but its statistical significance is a question. Attention should be paid to Figure 1, as the day $t$ in equation (1) is between $T_{0}$ and $T_{1}$ (this period can be denoted by $L_{1}$ ) and in formula (2) it is between $T_{1}$ and $T_{2}$ (this period can be denoted by $L_{2}$ ), with 0 indicating the day of the event.

Figure 1: Event study timeline 


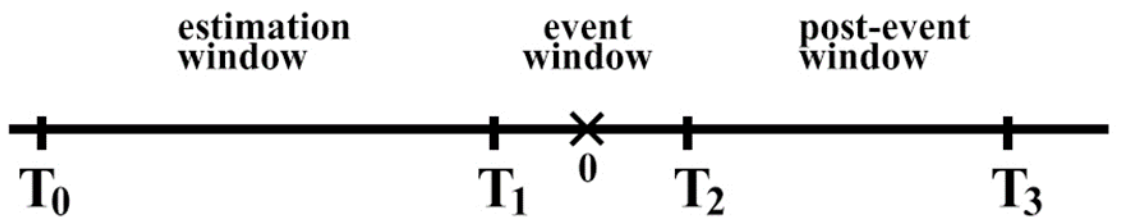

Source: Campbell, Lo, \& MacKinlay (1997)

Aggregation of abnormal returns is performed for analysis purposes. The aggregation can be performed in several dimensions: the first one is at daily level, for each day of the event window, whereby the average abnormal return on day $t, \overline{A R}$, can be determined:

$\overline{A R}_{t}=\frac{1}{N} \sum_{i=1}^{N} A R_{i t}$

$\operatorname{Var}\left(\overline{A R}_{t}\right)=\frac{1}{N^{2}} \sum_{i=1}^{N} \sigma_{\varepsilon_{i}}^{2}$

The second one is for each individual cryptocurrency over selected event window days. In most cases, aggregation is done for the entire event window. It results in a cumulative abnormal return $C A R_{i}$ of the cryptocurrency $i$ :

$$
\begin{aligned}
& \operatorname{CAR}_{i\left(t_{1}, t_{2}\right)}=\sum_{t=t_{1}}^{t_{2}} A R_{i t}, \quad T_{1}<t_{1} \leq t_{2} \leq T_{2} \\
& \operatorname{Var}\left(\operatorname{CAR}_{i\left(t_{1}, t_{2}\right)}\right)=\sigma_{i\left(t_{1}, t_{2}\right)}^{2}=\left(t_{2}-t_{1}+1\right) \sigma_{\varepsilon_{i}}^{2}
\end{aligned}
$$

Finally, the average cumulative abnormal return $\overline{C A R}$ can be determined. It should be kept in mind that both $C A R$ and $\overline{C A R}$ do not have to be calculated for the entire event window, but for any two or more related days.

$\overline{\operatorname{CAR}}_{\left(t_{1}, t_{2}\right)}=\frac{1}{N} \sum_{i=1}^{N} C A R_{i\left(t_{1}, t_{2}\right)}$

$\operatorname{Var}\left(\overline{\operatorname{CAR}}_{\left(t_{1}, t_{2}\right)}\right)=\frac{1}{N^{2}} \sum_{i=1}^{N} \sigma_{i\left(t_{1}, t_{2}\right)}^{2}$ 
In the papers of Campbell, Lo, \& MacKinlay (1997) and Serra (2002) one can find a gradual derivation of all abnormal return categories. The condition for equations (3), (5), (7) and (9) is a high value of $L_{1}$ (MacKinlay, 1997). For the purposes of the analysis, a standardized cumulative abnormal return - SCAR - will be required. Standardization is done for each individual cryptocurrency by dividing the value of $C A R_{i}$ with standard deviation:

$\operatorname{SCAR}_{i\left(t_{1}, t_{2}\right)}=\frac{\operatorname{CAR}_{i\left(t_{1}, t_{2}\right)}}{\sigma_{i}}$

After determining all categories of abnormal return, the next step is testing their statistical significance. It should be emphasized that there are two types of tests most commonly applied - parametric and non-parametric ones. In this paper, authors will apply t-tests, $J_{1}$ and $J_{2}$ tests from the scope of parametric tests, and also $\mathrm{J}_{3}$ (sign test) and $\mathrm{J}_{4}$ (rank test - Corrado test) tests from the scope of nonparametric tests.

The purpose of t-test is to test the difference between the historical and the hypothetical value of observed variable. In this case, the t-test statistic can be determined as:

$t=\frac{\overline{A R}_{t}-A R_{O}}{s / \sqrt{N}}$

Hypothetical value of $A R_{0}=0$, thus t-statistic can be obtained by dividing the average abnormal return for any day of the event by the ratio of the standard deviation and the square root of the number of assets under consideration (Samitas \& Kenourgios, 2004). Since this is a two-sided test, the critical value for rejecting the null hypothesis is \pm 1.96 with a confidence level of $95 \%$.

$\mathrm{J}_{1}$ tests the $\overline{C A R}$ value, and $\mathrm{J}_{2}$ tests the $\overline{S C A R}$ value. The second one represents the average of all SCAR values for observed cryptocurrencies. The null hypothesis states that the values of $\overline{C A R}$ and $\overline{S C A R}$ are equal to 0 , the alternative hypothesis rejects null. The critical values for two-sided tests are also \pm 1.96 with a confidence level of $95 \%$.

$J_{1}=\frac{\overline{C A R}_{\left(t_{1}, t_{2}\right)}}{\sqrt{\bar{\sigma}_{i\left(t_{1}, t_{2}\right)}^{2}}}$

$J_{2}=\sqrt{\left(\frac{N\left(L_{1}-4\right)}{L_{1}-2}\right)} \overline{\operatorname{SCAR}}_{\left(t_{1}, t_{2}\right)}$ 
The sign test determines the distribution of observed statistics in sample around the median value. The null hypothesis states that there is a symmetric distribution of positive and negative values of the observed statistics; the alternative hypothesis rejects the null hypothesis, with the conclusion that the distribution is asymmetric. In this case, the observed statistics is the cumulative abnormal return. The formula for calculating $J_{3}$ statistic is given as equation (14). $\mathrm{N}$ is the total number of observed cryptocurrencies, and $\mathrm{N}^{+(-)}$represents the number of positive or negative values of statistics (in this case the number of positive or negative $C A R$ values). The critical value of the test is \pm 1.64 in the case of the two-sided test.

$J_{3}=\left(\frac{N^{+(-)}}{N}-0.5\right) \frac{\sqrt{N}}{0.5}$

Corrado test examines the rank of the returns for each observed cryptocurrency during the event window. Both estimation window and event window combined make observation period for this test. Its advantage lies in the fact that the only important parameters for the analysis are the ranks of the returns, and not their signs. The null hypothesis is that ranks of returns during event window do not have extreme values; the alternative hypothesis rejects the null hypothesis with the conclusion that their values are extreme. The formula for calculating $\mathrm{J}_{4}$ statistic (15) is given by Cowan (1992) and Kolari, \& Pynnonen (2011). In equation (16), $\left(L_{2}+1\right) / 2$ represents the median rank, $K_{i o}$ is the rank of the cryptocurrency i on the day t, while $S\left(L_{2}\right)$ represents the standard deviation of the rank of return. The critical value of the test is \pm 1.64 in the case of the two-sided test.

$J_{4}=\frac{1}{N} \sum_{i=1}^{N}\left(K_{i t}-\frac{L_{2}+1}{2}\right) / S\left(L_{2}\right)$

$S\left(L_{2}\right)=\sqrt{\frac{1}{L_{2}} \sum_{t=T_{0}+1}^{T_{2}}\left(\frac{1}{N} \sum_{i=1}^{N}\left(K_{i t}-\frac{L_{2}+1}{2}\right)\right)^{2}}$

The effects of the forks will be observed on a sample of 8 representative cryptocurrencies. The basic criterion for selection was the market capitalization, as the aim was to measure the effect on those cryptocurrencies that have market significance. Thus, from the group of 15 largest cryptocurrencies, those that meet the additional requirements were selected. The first additional condition was that cryptocurrency existed during the estimation windows, while the second one was that cryptocurrency was not stable-coin. By definition, stable-coin has a value closely tied to a convertible currency and does not suffer 
from high value fluctuations. The first additional condition excluded EOS, Binance Coin, Cardano, and TRON from the analysis, while the second excluded Tether. Thus, for the first two events, following cryptocurrencies were selected: Bitcoin (BTC), Ether (ETH), Ripple (XRP), Litecoin (LTC), Ethereum Classic (ETC), Monero (XMR), Stellar (XLM) and Dash (DASH). For the third event, Bitcoin Cash was also included in the analysis, as it was the subjects of the fork.

The biggest issue for the analysis was to choose adequate market indicator to determine the expected return. When analyzing a stock market, an index of that specific market is used. The problem with the cryptocurrency market is that there is no generally accepted index, while many companies have created their own variants of the market index, which primarily serve as an investment vehicle (Trimborn, \& Härdle, 2018). For the purpose of this paper, the Crypto Currency Index 30 (CCi30) was selected, as its value is determined on the basis of the currently thirty largest cryptocurrencies. The motive for choosing this index was the width of market coverage.

For the purpose of the analysis, a four-day event period asymmetrical to the future $\left(T_{0}-T_{+3}\right)$ is constructed for each event. Due to the high volatility of all observed cryptocurrencies, wider estimation windows of 8 months were constructed. The first event included historical data starting from December 1 , 2016, up to August 5, 2017. The second event included historical data starting from February 24, 2017, up to October 28, 2017. The third event included historical data starting from March 15, 2018, up to November 19, 2018. For all three events, historical data were obtained from the coinmarketcap.com website. All calculations were done using SPSS 22 software.

\section{Results and discussion}

The resulting tests statistics are shown in Table 3 . The underlined values represent statistically significant abnormal returns.

Table 3: Values of tests statistics for each of the events

\begin{tabular}{|c|c|c|c|c|c|c|}
\hline Sectors & Period & t-test & $J_{1}$ & $\mathrm{~J}_{2}$ & $J_{3}$ & $\mathrm{~J}_{4}$ \\
\hline \multirow{4}{*}{$\mathrm{BCH}$ fork } & $T_{0}$ & 1.82998 & \multirow{4}{*}{$\underline{2.19075}$} & \multirow{4}{*}{0.48057} & \multirow{4}{*}{0} & 1.10115 \\
\hline & $T_{+1}$ & -3.16351 & & & & -0.72211 \\
\hline & $\mathrm{T}_{+2}$ & 1.35921 & & & & 0.83361 \\
\hline & $T_{+3}$ & 0.58996 & & & & 0.41150 \\
\hline \multirow{2}{*}{ BTG fork } & $\mathrm{T}_{0}$ & 0.95454 & \multirow{2}{*}{$\underline{-4.10754}$} & \multirow{2}{*}{$\underline{-5.07723}$} & \multirow{2}{*}{$\underline{-2.82843}$} & 0.74301 \\
\hline & $T_{+1}$ & -1.75934 & & & & -0.05522 \\
\hline
\end{tabular}




\begin{tabular}{|c|c|c|c|c|c|c|}
\hline & $T_{+2}$ & -3.01563 & & & & -0.13053 \\
\hline & $\mathrm{T}_{+3}$ & -9.95832 & & & & -0.50706 \\
\hline \multirow{4}{*}{ BSV fork } & $\mathrm{T}_{0}$ & -1.60655 & \multirow{4}{*}{$\underline{-2.96610}$} & \multirow{4}{*}{$\underline{-2.86725}$} & \multirow{4}{*}{-1.66667} & -0.49057 \\
\hline & $T_{+1}$ & -3.88527 & & & & -0.92779 \\
\hline & $T_{+2}$ & 0.27739 & & & & -0.01487 \\
\hline & $T_{+3}$ & $\underline{3.99054}$ & & & & 0.70568 \\
\hline
\end{tabular}

Author according the test results; underlined results are statistically significant

Based on Table 3, it can be concluded that selected cryptocurrencies reacted differently during the observed events. In the case of $\mathrm{BCH}$ fork, no statistically significant abnormal return is recorded. The t-test shows statistically significant negative abnormal return only on $\mathrm{T}_{+1}$ day. One might conclude that this is an evidence of market negative reaction to the completed fork, but no other test confirms it. The remaining three t-test statistics have a positive sign and no statistical significance. As for the tests that give unique statistics for the entire event window, only $J_{1}$ shows a statistically significant abnormal return, but in this case it is positive. Test statistic $J_{3}$ has a value of 0 , which indicates an equal distribution of positive and negative values of the observed statistics. On top of that, the $\mathrm{J}_{4}$ test statistic does not show statistical significance for any day of the event window.

Market reaction is quite opposite during other two events. In the case of BTG fork, multiple tests confirm statistical significance of the negative abnormal return. The t-test shows statistically significant negative abnormal return on $T_{+2}$ and $T_{+3}$ days. In addition, t-test statistic on $T_{+1}$ day also has a negative sign. All three tests that provide unique statistics for the entire event window confirm the existence of statistically significant negative abnormal return. However, the $J_{4}$ test does not confirm those conclusions. The statistics are negative on all postevent days, but none of them shows significance. As a result, the rank test fails to confirm the results of the other tests.

In the case of $B S V$ fork, the tests show results similar to those obtained during $B T G$ fork event. The t-test shows statistically significant negative abnormal return on $T_{+1}$ day and statistically significant positive abnormal return on $T_{+3}$ day. The event day also produces a negative abnormal return, but the value of statistic is slightly below the limit. All three tests that provide unique statistics for the entire event window confirm the existence of statistically significant negative abnormal return. However, the $J_{4}$ test again does not confirm those conclusions. The statistics are far from the threshold in all four days of the event window. As a result, the rank test fails to confirm the results of the other tests.

Based on tests results, one can conclude that not all hypotheses are supported. Statistical tests have not proven that the fork that led to the creation of Bitcoin 
Cash produced negative effects on the cryptocurrency market. Most of the statistics have no significance, and more than half of them have a positive value. Therefore, it can be concluded that $\mathrm{H}_{1}$ is not supported by the results of the analysis. However, statistical tests, except for the $\mathrm{J}_{4}$ test, showed that those forks that led to the creation of Bitcoin Gold and Bitcoin SV produced significant negative effects on the cryptocurrency market. The majority of statistics have negative values and show statistical significance. Therefore, it can be concluded that $\mathrm{H}_{2}$ and $\mathrm{H}_{3}$ are supported by the results of the analysis.

\section{Conclusion}

The objective of the study was to determine whether the Bitcoin forks produced significant effects on the cryptocurrency market. All events were expected to have negative effects. However, the study showed that the emergence of $\mathrm{BCH}$ was not accompanied by statistically significant negative abnormal return. Except for the t-test on $T_{+1}$ day, no other test showed the negative effect. The statistically significant positive value of the $J_{1}$ test was particularly unexpected. The market moved almost equally in both directions during the event period, which is confirmed by the zero value of $J_{3}$ test statistics. Therefore, there was no evidence to support the first hypothesis. These results confirm claims presented by Thompson (2017), that newly created cryptocurrency takes the majority of negative effects. Results are also in line with findings presented by Hashemi Joo, Nishikawa, \& Dandapani (2020), that the effect of this fork was mild but positive, and also with the ones presented by Kumar, \& Adandaro (2019) that the overall effect on market return was insignificant.

Tests proved that there was a significant negative effect in the case of the other two events. It was confirmed by statistically significant negative values of the ttests statistics as well as the $J_{1}, J_{2}$ and $J_{3}$ tests statistics. During the second event, test statistics had particularly high negative values, and none of those that had positive value showed statistical significance. The tests showed significant negative effects of the emergence of BSV as well. Therefore, it can be concluded that tests proved enough evidence to support the second and third hypotheses. Results related to the emergence of BTG are in line with the study conducted by Bouri, Roubaud, \& Shahzad (2020). However, results are not coresponding those obtained by Kumar, \& Adandaro (2019), Agosto, \& Cafferata (2020), nor the claims presented by Thompson (2017). The explanation could be that none of these researches were event study so that they had different time perspectives. Instead of focusing on the day of the event and the following few days, the authors observed a wider time horizon. As the 
total cryptocurrency market continued to grow, these authors concluded that there was no negative effect.

One the most interesting findings, is the absence of any statistically significant value of the $J_{4}$ statistics. The value of these statistics is relatively low during all days of the event periods, and has value higher than 1 only on the event day during the first observed event. These results are inconsistent with other tests, but they still have plausible explanation. The value of rank test statistics depends on the ranks of returns on the event windows days. However, ranking is done over very long period of time (estimation window + event window). In other words, it is possible that the abnormal returns during event window have negative value that shows statistical significance, but that their ranks are not high enough, because there are many other negative abnormal returns during the estimation window. The closer abnormal return rank is to the middle, the lower are the chances for $\mathrm{J}_{4}$ statistic to be statistically significant. This is precisely the case in all three events that were subjects of analysis. The absence of statistical significance in the rank test confirms the earlier assertion that the returns of cryptocurrencies change abruptly and that the amplitudes of these oscillations are very pronounced.

The number of selected cryptocurrencies is the main limitation of the research. However, an inclusion of a wider market share could create a problem with the relevance of the selected cryptocurrencies. The cryptocurrency market is characterized by extremely high concentration. In the event study, all forms of assets (in this case cryptocurrency) that are observed are treated as equal. It could lead to a situation in which cryptocurrencies that actually have a low market share could give the statistical significance to the test. This is why the inclusion of too many cryptocurrencies with low market capitalization may give a wrong impression of the market reaction. With a carefully chosen wider sample, the future researches should analyze other famous forking cases, for example the Ethereum forks.

\section{References}

Agosto, A., \& Cafferata, A. (2020). Financial bubbles: A study of co-explositivity in cryptocurrency market. Risks 2020, 8(2), 34-48. https://doi.org/10.3390/risks8020034

Ante, L. (2019). Market reaction to exchange listings of cryptocurrencies. Blockchain Research Lab Working Paper Series (3), Retrieved from SSRN: https://ssrn.com/abstract=3450301 
Borgards, O., \& Czudaj, R. (2020). The prevalence of price overreaction in the cryptocurrency market. Journal of international financial markets, institutions and money, 65. https://doi.org/10.1016/j.intfin.2020.101194

Bouri, E., Roubaud, D., \& Shahzad, S.J.H. (2020). Do Bitcoin and other cryptocurrencies jump together? The Quarterly Review of Economics and Finance, 76, 396-409. https://doi.org/10.1016/j.qref.2019.09.003

Brown, S., \& Warner, J. (1980). Measuring security price performance. Journal of financial economics, 8(3), 205-258. https://doi.org/10.1016/0304-405x(80)900021

Brown, S., \& Warner, J. (1985). Using daily stock returns. Journal of financial economics, 14(1), 3-31. https://doi.org/10.1016/0304-405x(85)90042-x

Campbell, J.Y., Lo, A.W., \& MacKinlay, A.C. (1997). The Econometrics of Financial Markets ( $2^{\text {nd }}$ ed.). Princeton, NJ: Princeton university press.

Chaparro, F. (2017). Bitcoin is sliding after bitcoin gold goes live. Business Insider, October 24. Retrieved from https://www.businessinsider.in/bitcoin-is-sliding-afterbitcoin-gold-goes-live/articleshow/61207903.cms

Corrado, C.J. (1989). A nonparametric test for abnormal security-price performance in event studies. Journal of financial economics, 23(2), 385-395. https://doi.org/10.1016/0304-405x(89)90064-0

Cowan, A.R. (1992). Nonparametric Event Study Tests. Review of Quantitative Finance and accounting, 2(4), 343-358. https://doi.org/10.1007/bf00939016

De Filippi, P., \& Loveluck, B. (2016). The invisible politics of bitcoin: governance crisis of a decentralized infrastructure. Internet policy review, 5(4), 1-28. https://doi.org/10.14763/2016.3.427

Dodd, P., \& Warner, J.B. (1983). On corporate study: A study of Proxy contest. Journal of Financial Economics, 11(1-4), 401-438. https://doi.org/10.1016/0304-405X (83) 90018-1

Dolley, J. (1933). Characteristics and procedure of common stock split-ups. Harvard business review, 11, 316-326

Enoksen, F.A., Landsnes, Ch. J., Lučivjánka, K., \& Molnár, P. (2020). Understanding risk of bubbles in cryptocurrencies. Journal of Economic Behavior \& Organization, 176, 129-144. https://doi.org/10.1016/j.jebo.2020.05.005

Fama, E., Fischer, L., Jensen, M.C., \& Roll, R. (1969). The adjustment of stock prices to new information. International Economic Review, 10(1), 1-2. https://doi.org/10.2307/2525569

Fenech, G. (2018). Bitcoin Cash Forks -- Mayhem On the Markets. Forbes, November 16. Retrieved from https://www.forbes.com/sites/geraldfenech/2018/11/16/bitcoin-cash-forksmayhem-on-the-markets/\#3cb44de377ed

Hashemi Joo, M., Nishikawa, Y., \& Dandapani, K. (2020). Announcement effects in the cryptocurrency market. Applied Economics, 52(44), 4794-4808. https://doi.org/10.1080/00036846,2020,1745747

Islam, N., Mäntymäki, M., \& Turunen, M. (2019). Why do blockchains split? An actornetwork perspective on Bitcoin splits. Technological Forecasting and Social Change, 148. https://doi.org/10.1016/j.techfore.2019.119743

Kolari, J.W., \& Pynnonen, S. (2011). Nonparametric rank test for event studies. Journal of empirical Finance, 18(5), 953-971.

Industrija, Vol.48, No.2, 2020 
https://doi.org/10.1016/j.jempfin.2011.08.003

Kumar, A.S., \& Anandarao, S. (2019). Volatility spillover in cryptocurrency markets: Some evidence from $\mathrm{GARCH}$ and wavelet analysis. Physica A: Statistcial mechanics and application, 524, 448-458. https://doi.org/10.1016/j.physa.2019.04.154

Lee, D., \& Chen, K. (2017). Handbook of digital currency - Bitcoin, Innovation, Financial Instruments, and Big Data. London, UK: Elsevier

MacKinlay, A.C. (1997). Event Studies in Economics and Finance. Journal of Economic Literature, 35(1), 13-39. Retrieved from www.jstor.org/stable/2729691

Nakamoto, S. (2008) Bitcoin: A Peer-to-Peer Electronic Cash System. Retrieved from http://bitcoin.org

Samitas, A.G., \& Kenourgios, D.F. (2004) Market Efficiency and Signaling: An Event Study Analysis for Athens Stock Exchange. Paper presented at 1st Applied Financial Economics International Conference "Advances in Applied Financial Economics", Samos island, Greece. Retrieved from https://www.researchgate.net/publication/228542064_Market_Efficiency_and_Sig naling_An_Event_Study_Analysis for_Athens_Stock_Exchange

Serra, A.P. (2002). EVENT STUDY TESTS - A brief survey. Working Papers da FEP no. 117

Shanaev, S., Shuraeva, A., Vasenin, M., \& Kuznetsov, M. (2019). Cryptocurrency value and $51 \%$ attacks: Evidence from event studies. The Journal of Alternative Investments Winter 2020, 22(3), 65-77. https://doi.org/10.3905/jai.2019.1.081

Thompson, P. (2017). How Bitcoin forks influence Bitcoin price rise and fall, cointelegraph.com, October 28. Available at: https://cointelegraph.com/news/how-bitcoin-forks-influence-bitcoin-price-riseand-fall

Trimborn, S., \& Härdle, W.K. (2018) CRIX and index for cryptocurrencies. Journal of Empirical Finance, 49, 107-122, https://doi.org/10.1016/j.jempfin.2018.08.004

Williams-Grut, O., \& Price, R. (2017). A Bitcoin civil war is threatening to tear the digital currency in 2 - here's what you need to know. Business Insider, July 2 . Retrieved from https://markets.businessinsider.com/currencies/news/bitcoins-hard-forkbitcoin-unlimited-segregated-witness-explained-2017-3-1001867731\#

https://coinmarketcap.com/all/views/all/ (Retrieved August 19, 2020)

https://cointelegraph.com/news/the-cream-of-the-crypto-crop-10-best-performingassets-in-2017 (Retrieved March 20, 2020) 